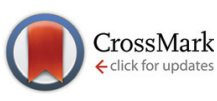

Cite this: Food Funct., 2016, 7, 1458

\title{
Bioactivity, proximate, mineral and volatile profiles along the flowering stages of Opuntia microdasys (Lehm.): defining potential applications
}

\author{
Hassiba Chahdoura, a,b,c João C. M. Barreira, ${ }^{* a}{ }^{a}$ Virginia Fernández-Ruiz, ${ }^{d}$ \\ Patricia Morales, ${ }^{d}$ Ricardo C. Calhelha, ${ }^{a}$ Guido Flamini, ${ }^{\text {,f }}$ Marina Soković, ${ }^{\mathrm{g}}$ \\ Isabel C. F. R. Ferreira*a and Lotfi Achour ${ }^{\text {b }}$
}

\begin{abstract}
Opuntia spp. flowers have been traditionally used for medical purposes, mostly because of their diversity in bioactive molecules with health promoting properties. The proximate, mineral and volatile compound profiles, together with the cytotoxic and antimicrobial properties were characterized in 0 . microdasys flowers at different maturity stages, revealing several statistically significant differences. 0 . microdasys stood out mainly for its high contents of dietary fiber, potassium and camphor, and its high activities against HCT15 cells, Staphylococcus aureus, Aspergillus versicolor and Penicillium funiculosum. The vegetative stage showed the highest cytotoxic and antifungal activities, whilst the full flowering stage was particularly active against bacterial species. The complete dataset has been classified by principal component analysis, achieving clearly identifiable groups for each flowering stage, elucidating also the most distinctive features, and comprehensively profiling each of the assayed stages. The results might be useful to define the best flowering stage considering practical application purposes.
\end{abstract}

Received 11th December 2015 Accepted 2nd February 2016

DOI: $10.1039 / \mathrm{c} 5$ fo0 $01536 \mathrm{~g}$

www.rsc.org/foodfunction sions in traditional Tunisian and in Sicilian medicine for their diuretic activity, capacity to help in renal calculus expulsion and to cure ulcer. ${ }^{4,5}$ In fact, different parts of Opuntia sp. are being increasingly used in nutritional and pharmacological applications (including at the industrial level). Nevertheless, the number of reports characterizing the chemical profiles of their flowers is still scarce, especially throughout their ripening, which motivated our present investigation.

The methanolic extracts from flowers of Opuntia microdasys (Lehm.) have been recently reported as containing high quantities of polyphenols (especially flavonoids) and a strong antioxidant activity. ${ }^{6}$ The interest in plant materials containing phenolic compounds is increasing due to their high antioxidant potency, which may offer protection against different diseases, such as cancer through the inhibition of oxidative damage (known for being a potential cause of mutation). ${ }^{7}$ Furthermore, there is a rising awareness regarding the use of volatiles in both the food and the pharmaceutical industries, justifying a systematic examination of plant extracts for these compounds. ${ }^{8}$

Despite only a few reports describe the volatile composition of Opuntia spp. flowers, it is possible to point out tetradecanoic acid, hexadecanoic acid, octadecadienoic acid and camphor as the main volatile compounds. ${ }^{9-11}$ Opuntia flowers have also been reported to contain high levels of minerals (e.g., $\mathrm{K}, \mathrm{Ca}, \mathrm{Mg}$ ) and fiber. ${ }^{12}$ Likewise, there are some published studies describing their antibacterial activity. ${ }^{11,12}$ 
However, the effect of the phenological stage in which the components are evaluated was not studied for this species. This is an important research topic, since the amounts and nature of compounds may vary along the flowering stage, suggesting changes in the secondary metabolism of flowers.

Overall, this study seeks to contribute to the knowledge of the nutritional value and biological properties of $O$. microdasys flowers, characterizing their potential use as a functional food. Furthermore, the flowers' volatile composition at different flowering stages has never been reported before in this species.

\section{Experimental}

\section{Samples}

Opuntia microdasys (Lehm.) flowers were collected in 2013 from the cliff of Monastir (Tunisia) at three phenological stages: (F1) the vegetative stage, with green closed petal flowers (harvested in the beginning of June); (F2) the full flowering stage: stamens are separated around the style, the flowers are fully opened and the nectar production starts (harvested after the first fortnight of June); (F3) the post flowering stage: the flowers are dried and close to senescence (obtained in the last week of June). Samples for analysis (50 $\mathrm{g}$ for each flowering stage) were dried in the shade, ground using a Warring blender (Phillips, France), reduced to a fine dried powder (20 mesh) and mixed to obtain a homogeneous sample.

\section{Standards and reagents}

Micro (Fe, $\mathrm{Cu}, \mathrm{Mn}$ and $\mathrm{Zn}$ ) and macroelement (Ca, $\mathrm{Mg}, \mathrm{Na}$ and K) standards (>99\% purity), as well as $\mathrm{LaCl}_{2}$ and $\mathrm{CsCl}(>99 \%$ purity) were purchased from Merck (Darmstadt, Germany). Mueller-Hinton agar (MH) and malt agar (MA) were obtained from the Institute of Immunology and Virology, Torlak (Belgrade, Serbia). Acetic acid, ellipticine, phosphate buffered saline (PBS), acetic acid, sulforhodamine B (SRB), trichloroacetic acid (TCA), Tris, streptomycin (Sigma-Aldrich S6501) and ampicillin (Sigma-Aldrich A9393) were purchased from Sigma (St Louis, MO, USA). Bifonazole (Srbolek, Belgrade, Serbia) and ketoconazole (Zorkapharma, Šabac, Serbia) were used as the reference fungicides.

Foetal bovine serum (FBS), L-glutamine, Hank's balanced salt solution (HBSS), trypsin-EDTA (ethylenediamine tetraacetic acid), nonessential amino acid solution ( $2 \mathrm{mM})$, penicillin/streptomycin solution $\left(100 \mathrm{U} \mathrm{mL}^{-1}\right.$ and $100 \mathrm{mg} \mathrm{mL} \mathrm{mL}^{-1}$, respectively), RPMI-1640 and DMEM media were from Hyclone (Logan, UT, USA). Dimethylsulfoxide (DMSO), (Merck KGaA, Darmstadt, Germany) was used as a solvent. Water was treated in a Milli-Q water purification system (TGI Pure Water Systems, Greenville, SC, USA). All other chemicals and solvents were of analytical grade and purchased from common sources.

\section{Proximate analysis and fiber composition}

The samples were analyzed for chemical composition (moisture, proteins, fat and carbohydrates) using the AOAC procedures. ${ }^{13}$ The crude protein content (AOAC 928.08) of the samples was estimated by the macro-Kjeldahl method $(\mathrm{N} \times$ 6.25); the crude fat (AOAC 991.36) was determined by extracting a known weight of the powdered sample with petroleum ether in a Soxhlet apparatus; the ash content was determined by incineration at $550 \pm 15{ }^{\circ} \mathrm{C}$. Total carbohydrates were calculated by subtracting the amounts of protein, ash and fat, considering $100 \mathrm{~g}$ of dried sample.

Soluble dietary fiber (SDF) and insoluble dietary fiber (IDF) were determined according to the AOAC enzymatic-gravimetric method (993.19 and 991.42). ${ }^{14}$ Freeze-dried samples were treated with alpha-amylase (heat-stable), protease and amyloglucosidase. The soluble and insoluble fractions were separated by vacuum filtration. Waste from the digests was dried at $100^{\circ} \mathrm{C}$. Total dietary fiber (TDF) was the sum of SDF and IDF; both were expressed as $\mathrm{g}$ per $100 \mathrm{~g}$ of dry weight.

The energy value was calculated according to the following equation: Energy (kcal per $100 \mathrm{~g} \mathrm{dw})=4 \times(\mathrm{g}$ protein $)+4 \times$ $(\mathrm{g}$ carbohydrate $-\mathrm{g}$ TDF $)+2 \times(\mathrm{TDF})+9 \times(\mathrm{g}$ fat $)$.

\section{Ash content and mineral composition}

The method 930.05 of AOAC was used. A sample of $500 \mathrm{mg}$ was incinerated under high pressure in a microwave oven (Muffle Furnace mLs1200, Thermo Scientific, Madrid, Spain) for $24 \mathrm{~h}$ at $550{ }^{\circ} \mathrm{C}$, and ashes were gravimetrically quantified. The residue of incineration was extracted with $\mathrm{HCl}(50 \%, \mathrm{v} / \mathrm{v})$ and $\mathrm{HNO}_{3}(50 \%, \mathrm{v} / \mathrm{v})$ and made up to an appropriate volume with distilled water, where $\mathrm{Fe}, \mathrm{Cu}, \mathrm{Mn}$ and $\mathrm{Zn}$ were directly measured. An additional 1/10 (v/v) dilution of the sample extracts and standards was performed to avoid interferences between different elements in the atomic absorption spectroscopy: for $\mathrm{Ca}$ and $\mathrm{Mg}$ analysis in $1.16 \% \mathrm{La}_{2} \mathrm{O}_{3} / \mathrm{HCl}$ (leading to $\mathrm{LaCl}_{2}$ ); and for $\mathrm{Na}$ and $\mathrm{K}$ analysis in $0.2 \% \mathrm{CsCl}^{15}$ All measurements were performed using atomic absorption spectroscopy (AAS) by using Analyst 200 Perkin Elmer equipment (Perkin Elmer, Waltham, MA, USA), comparing absorbance responses with $99.9 \%$ purity analytical standard solutions for AAS made with $\mathrm{Fe}\left(\mathrm{NO}_{3}\right)_{3}, \mathrm{Cu}\left(\mathrm{NO}_{3}\right)_{2}, \mathrm{Mn}\left(\mathrm{NO}_{3}\right)_{2}, \mathrm{Zn}\left(\mathrm{NO}_{3}\right)_{2}$, $\mathrm{NaCl}, \mathrm{KCl}, \mathrm{CaCO}_{3}$ and the $\mathrm{Mg}$ band, supplied by Merck (Darmstadt, Germany) and Panreac Química (Barcelona, Spain).

\section{Volatile compound analyses}

Supelco (Bellefonte, PA) SPME devices coated with poly-dimethylsiloxane (PDMS, $100 \mu \mathrm{m}$ ) were used to sample the headspace of a dry flower inserted into a $5 \mathrm{~mL}$ vial and allowed to equilibrate for $30 \mathrm{~min}$. SPME sampling was performed using the same new fiber, preconditioned according to the manufacturer's instructions, for all the analyses. Sampling was accomplished in an air-conditioned room $\left(22 \pm 1^{\circ} \mathrm{C}\right)$ to guarantee a stable temperature. After the equilibration time, the fiber was exposed to the headspace for $50 \mathrm{~min}$ at room temperature. Once sampling was finished, the fiber was withdrawn into the needle and transferred to the injection port of the GC-MS system. All the SPME sampling and desorption conditions were identical for all the samples. Furthermore, blanks were performed before each first SPME extraction and randomly repeated during each series. Quantitative comparisons of rela- 
tive peak areas were performed between the same chemicals in the different samples.

GC-Electron Impact Mass Spectrometry (EIMS) analyses were performed with a Varian (Palo Alto, CA) CP3800 gas chromatograph equipped with a DB-5 capillary column $(30 \mathrm{~m} \times$ $0.25 \mathrm{~mm} \times 0.25 \mu \mathrm{m}$; Agilent, Santa Clara, CA, USA) and a Varian Saturn 2000 ion trap mass detector. Analytical conditions were as follows: injector and transfer line temperatures were 220 and $240{ }^{\circ} \mathrm{C}$, respectively; the oven temperature was programmed from 60 to $240{ }^{\circ} \mathrm{C}$ at $3{ }^{\circ} \mathrm{C} \mathrm{min}^{-1}$; the carrier gas

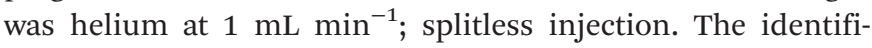
cation of the constituents was based on a comparison of the retention times with those of authentic standards, which comprise all the compounds indicated in Table 3, except iso-pentyl acetate, valerolactone, 2-pentyl furan, $(E, Z)$-3,5-octadien-2-one, $(E, E)$-3,5-octadien-2-one, 1-nonen-3-ol, $\beta$-selinene and dihydroactinidiolide, which were identified according to their MS spectra and linear retention indices (LRI), and on computer matching against commercial and home-made library mass spectra and data, specifically NIST 2000 and ADAMS $2007 .^{16}$

\section{Cytotoxicity assays}

General. Each sample ( $\sim \mathrm{g}$ of freeze-dried powder) was extracted by stirring with $40 \mathrm{~mL}$ of methanol at $25^{\circ} \mathrm{C}$ for $1 \mathrm{~h}$ and filtered through Whatman no. 4 filter paper. The residue was then extracted with an additional $40 \mathrm{~mL}$ portion of methanol. The combined methanolic extracts were evaporated under reduced pressure (rotary evaporator Büchi R-210, Flawil, Switzerland), re-dissolved in water at a concentration of $8 \mathrm{mg}$ $\mathrm{mL}^{-1}$, and stored at $4{ }^{\circ} \mathrm{C}$ until determination of $\mathrm{GI}_{50}$ values (concentration that inhibited $50 \%$ of the net cell growth; expressed in $\mu \mathrm{g} \mathrm{mL}^{-1}$ ). Ellipticine was used as a positive control.

Evaluation of cytotoxicity in human tumor cell lines. Four human tumor cell lines were used: HCT15 (colon carcinoma), HeLa (cervical carcinoma), HepG2 (hepatocellular carcinoma) and MCF-7 (breast adenocarcinoma). Cells were routinely maintained as adherent cell cultures in RPMI-1640 medium containing $10 \%$ heat-inactivated FBS and $2 \mathrm{mM}$ glutamine (MCF-7 and HCT15) or in DMEM supplemented with 10\% FBS, $2 \mathrm{mM}$ glutamine, $100 \mathrm{U}$ per $\mathrm{mL}$ penicillin and $100 \mathrm{mg}$ per $\mathrm{mL}$ streptomycin (HeLa and HepG2 cells), at $37{ }^{\circ} \mathrm{C}$, in a humidified air incubator containing $5 \% \mathrm{CO}_{2}$. Each cell line was plated at an appropriate density $\left(7.5 \times 10^{3}\right.$ cells per well for MCF-7 and HCT15 or $1.0 \times 10^{4}$ cells per well for HeLa and HepG2) in 96-well plates and allowed to attach for $24 \mathrm{~h}$. Cells were then treated for $48 \mathrm{~h}$ with various extract concentrations. Following this incubation period, the adherent cells were fixed by adding cold $10 \%$ trichloroacetic acid (TCA, $100 \mu \mathrm{L}$ ) and incubated for $60 \mathrm{~min}$ at $4^{\circ} \mathrm{C}$. Plates were then washed with deionized water and dried; sulforhodamine B solution $(0.1 \%$ in $1 \%$ acetic acid, $100 \mu \mathrm{L}$ ) was then added to each plate well and incubated for $30 \mathrm{~min}$ at room temperature. Unbound SRB was removed by washing with $1 \%$ acetic acid. Plates were air-dried, the bound SRB was solubilized with $10 \mathrm{mM}$ Tris $(200 \mu \mathrm{L})$ and the absor- bance was measured at $540 \mathrm{~nm}$ using an ELX800 Microplate Reader (Bio-Tek Instruments, Inc.; Winooski, VT, USA). ${ }^{17}$

Evaluation of cytotoxicity in a porcine liver primary cell culture. A cell culture was prepared from a freshly harvested porcine liver obtained from a local slaughter house, and it was designed as PLP2. Briefly, the liver tissues were rinsed in Hank's balanced salt solution containing $100 \mathrm{U}$ per $\mathrm{mL}$ penicillin, $100 \mu \mathrm{g}$ per $\mathrm{mL}$ streptomycin and divided into $1 \times 1 \mathrm{~mm}^{3}$ explants. Some of these explants were placed in $25 \mathrm{~cm}^{2}$ tissue flasks in DMEM medium supplemented with 10\% fetal bovine serum, $2 \mathrm{mM}$ non-essential amino acids and $100 \mathrm{U}$ per $\mathrm{mL}$ penicillin, $100 \mathrm{mg}$ per $\mathrm{mL}$ streptomycin and incubated at $37{ }^{\circ} \mathrm{C}$ under a humidified atmosphere containing $5 \% \mathrm{CO}_{2}$. The medium was changed every two days. Cultivation of the cells was continued with direct monitoring every two to three days using a phase contrast microscope. Before confluence was reached, cells were subcultured and plated in 96-well plates at a density of $1.0 \times 10^{4}$ cells per well, and cultivated in DMEM medium with $10 \%$ FBS, $100 \mathrm{U}$ per $\mathrm{mL}$ penicillin and $100 \mu \mathrm{g}$ per mL streptomycin. ${ }^{17}$

\section{Evaluation of the antimicrobial activity}

General. The methanolic extracts were re-dissolved in a $5 \%$ solution of DMSO in distilled water at $100 \mathrm{mg} \mathrm{mL}^{-1}$. Successive dilutions were made from the stock solution and subjected to antibacterial and antifungal assays. Bacterial and fungal organisms were obtained from the Mycological Laboratory, Department of Plant Physiology, Institute for Biological Research "Sinisa Stanković", University of Belgrade, Serbia. DMSO (5\%) was used as a negative control.

Antibacterial activity. The following Gram-positive bacteria: Staphylococcus aureus (ATCC 6538), Bacillus cereus (clinical isolate), Micrococcus flavus (ATCC10240), and Listeria monocytogenes (NCTC7973) and Gram-negative bacteria: Escherichia coli (ATCC 35210), Pseudomonas aeruginosa (ATCC 27853), Salmonella typhimurium (ATCC 13311), and Enterobacter cloacae (ATCC 35030) were used.

The minimum inhibitory (MIC) and minimum bactericidal (MBC) concentrations were determined by the microdilution method. Briefly, a fresh overnight culture of bacteria was adjusted using a spectrophotometer to a concentration of $1 \times$ $10^{5} \mathrm{CFU} \mathrm{mL}{ }^{-1}$. The requested $\mathrm{CFU} \mathrm{mL}^{-1}$ corresponded to a bacterial suspension determined using a spectrophotometer at $625 \mathrm{~nm}\left(\mathrm{OD}_{625}\right)$. Dilutions of inocula were cultured on a solid medium to verify the absence of contamination and check the validity of the inoculum. Different solvent dilutions of the methanolic extract/fractions were placed in the wells containing $100 \mu \mathrm{L}$ of tryptic soy broth (TSB) and afterwards $10 \mu \mathrm{L}$ of inoculum was added. The microplates were incubated for $24 \mathrm{~h}$ at $37^{\circ} \mathrm{C}$.

The minimum inhibitory concentration (MIC) of each extract was detected following the addition of $40 \mu \mathrm{L}$ of iodonitrotetrazolium chloride (INT) $\left(0.2 \mathrm{mg} \mathrm{mL}^{-1}\right)$ and incubation at $37{ }^{\circ} \mathrm{C}$ for $30 \mathrm{~min}$. The lowest concentration that produced a significant inhibition (around 50\%) of the growth of the bac- 
teria in comparison with the positive control was identified as the MIC. The minimum bactericidal concentration (MBC) was determined by serial subculture of $10 \mu \mathrm{L}$ into microplates containing $100 \mu \mathrm{L}$ of TSB. The lowest concentration not showing growth after this subculturing was read as the MBC. Standard drugs, namely, streptomycin and ampicillin, were used as positive controls. DMSO (5\%) was used as a negative control.

Antifungal activity. For the antifungal bioassays, the following microfungi were used: Aspergillus fumigatus (ATCC1022), Aspergillus ochraceus (ATCC12066), Aspergillus versicolor (ATCC11730), Aspergillus niger (ATCC6275), Penicillium funiculosum (ATCC 36839), Penicillium ochrochloron (ATCC9112), Penicillium verrucosum var. cyclopium (food isolate), and Trichoderma viride (IAM 5061). The micromycetes were maintained on malt agar (MA) and the cultures were stored at $4{ }^{\circ} \mathrm{C}$ and subcultured once a month. ${ }^{18}$ The fungal spores were washed from the surface of agar plates with sterile $0.85 \%$ saline containing $0.1 \%$ Tween $80(\mathrm{v} / \mathrm{v})$. The spore suspension was adjusted with sterile saline $\left(\approx 1.0 \times 10^{3} \mu \mathrm{L}^{-1}\right.$ per well $)$. The inocula were stored at $4{ }^{\circ} \mathrm{C}$ for further use. Dilutions of the inocula were cultured on solid MA to verify the absence of contamination and to check the validity of the inoculum.

MIC determination was performed by a serial dilution technique using 96-well microtitre plates. The extracts were dissolved in a $5 \%$ solution of DMSO and added to a broth malt medium with fungal inoculum. The microplates were incubated for $72 \mathrm{~h}$ at $28{ }^{\circ} \mathrm{C}$. The lowest concentrations without visible growth (at the binocular microscope) were defined as MIC. The minimum fungicidal concentration (MFC) was determined by serial subculture of $2 \mu \mathrm{L}$ in microtitre plates containing $100 \mu \mathrm{L}$ of malt broth per well and further incubation for $72 \mathrm{~h}$ at $28{ }^{\circ} \mathrm{C}$. The lowest concentration with no visible growth was defined as the MFC, indicating 99.5\% killing of the original inoculum. Bifonazole and ketoconazole were used as positive controls. $^{19}$

Statistical analysis. For all the experiments three samples $(n=3)$ were analyzed and all the assays were carried out in triplicate. The results are expressed as mean values \pm standard deviation (SD), except for antimicrobial assays. All statistical tests were performed at a 5\% significance level using IBM SPSS Statistics for Windows, version 22.0. (IBM Corp., USA).

The differences between the flowering stages were analyzed using one-way analysis of variance (ANOVA). The fulfilment of the one-way ANOVA requirements, specifically the normal distribution of the residuals and the homogeneity of variance, was tested by means of the Shapiro Wilk and the Levene tests, respectively. All dependent variables were compared using Tukey's honestly significant difference (HSD) or Tamhane's T2 multiple comparison tests, when homoscedasticity was verified or not, respectively.

Principal component analysis (PCA) was applied as a pattern recognition unsupervised classification method. The number of dimensions to keep for data analysis was assessed by the respective eigenvalues (which should be greater than one), by Cronbach's alpha parameter (that must be positive) and also by the total percentage of variance (that should be as high as possible) explained by the number of components selected. The number of plotted dimensions was chosen in order to allow meaningful interpretations.

\section{Results and discussion}

\section{Proximate composition and dietary fiber}

The results for the proximate composition value are shown in Table 1. At the first two flowering stages, water was the major component (more than $80 \mathrm{~g}$ per $100 \mathrm{~g} \mathrm{fw}$ ), but it drastically decreases at the post-flowering stage (19.6 g per $100 \mathrm{~g} \mathrm{fw}$ ). On a dry weight ( $\mathrm{dw}$ ) basis, carbohydrates were the most abundant macronutrients (more than $80 \mathrm{~g}$ per $100 \mathrm{~g} \mathrm{dw}$ ) at all flowering stages, showing slightly higher values at the full flowering stage. Most (around 70\%) of these carbohydrates were present as total dietary fiber (TDF), especially in insoluble forms. In

Table 1 Nutritional and dietary fiber composition ( $\mathrm{g}$ per $100 \mathrm{~g} \mathrm{dw}$; mean $\pm \mathrm{SD}, n=9$ ) of the three flowering stages of Opuntia microdasys (Lehm.)

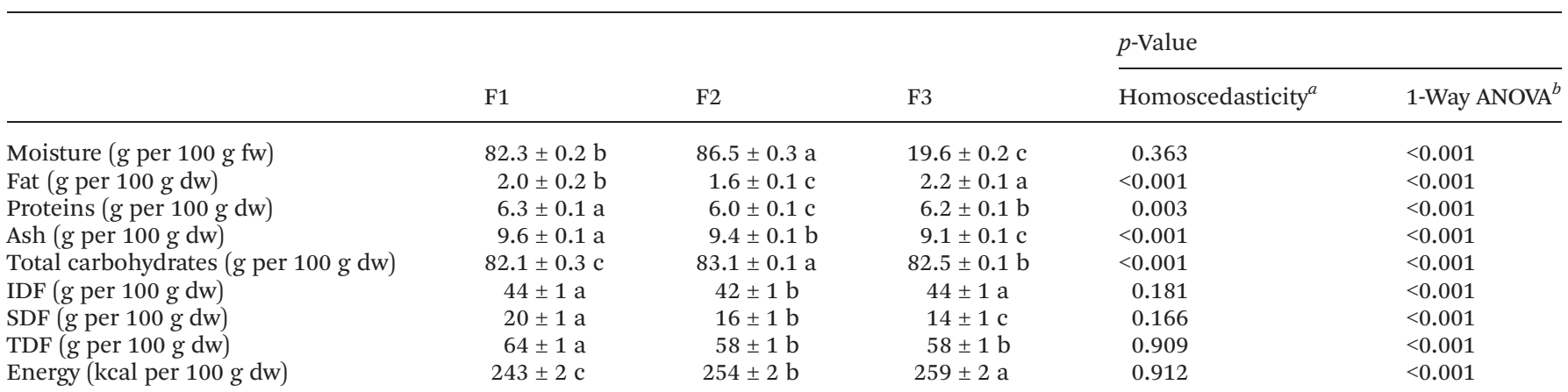

dw: dry weight; fw: fresh weight; F1: vegetative stage, F2: full flowering stage, F3: post-flowering stage. IDF: insoluble dietary fiber; SDF: soluble dietary fiber; TDF: total dietary fiber. ${ }^{a}$ Homoscedasticity among the flowering stages was tested by the Levene test: homoscedasticity, $p>0.05$; heteroscedasticity, $p<0.05 .{ }^{b} p<0.05$ indicates that the mean value of the evaluated parameter of at least one flowering stage differs from the others (in this case multiple comparison tests were performed). For each stage, means within a row with different letters differ significantly $(p<0.05)$. 
comparison with other species of the genus Opuntia, the TDF values were higher than those reported by Ammar et al. ${ }^{20}$ for $O$. ficus-indica and O. stricta. Furthermore, it is recommended that a third of TDF of the diet (approximately $20 \mathrm{~g}$ in the present case) should be soluble dietary fiber, and the distribution of dietary fiber in the three flowering stages is in agreement with the nutritional recommendations. ${ }^{21}$ In fact, these results are noticeable, even when compared to the dietary fiber contents detected in some cereal sources, ${ }^{22}$ raising the possibility of using $O$. microdasys flowers as a potential source of dietary fiber and/or to be added as a food ingredient to other food products to improve the fiber intake of the population.

In addition, O. microdasys flowers showed significant ash contents (higher than $9 \mathrm{~g}$ per $100 \mathrm{~g} \mathrm{dw}$ ) and proteins (higher than $6 \mathrm{~g}$ per $100 \mathrm{~g} \mathrm{dw}$ ), both components with minor differences among the flowering stages. Fat was the least abundant component (around $2 \mathrm{~g}$ per $100 \mathrm{~g} \mathrm{dw}$ ), with slightly higher values at the post flowering stage. In general, the moisture content in F1 and F2 was similar to the one quantified in the cladodes (92 g per $100 \mathrm{~g} \mathrm{fw}$ ) and pulps (87 g per $100 \mathrm{~g} \mathrm{fw}$ ) of this species. Fat levels in all flowering stages were close to the ones detected in the pulp ( $2.46 \mathrm{~g}$ per $100 \mathrm{~g} \mathrm{dw}$ ), while protein contents were comparable to those measured in the cladodes $(4.25 \mathrm{~g}$ per $100 \mathrm{~g} \mathrm{dw})$. Ash contents were lower than the ones quantified in the cladodes $(16.4 \mathrm{~g}$ per $100 \mathrm{~g} \mathrm{dw})$ and pulps (16.4 $\mathrm{g}$ per $100 \mathrm{~g} \mathrm{dw}$ ), whilst carbohydrates were nearly the same. ${ }^{23}$ The flowers' nutritional profiles resulted in energetic values close to $250 \mathrm{kcal}$ per $100 \mathrm{~g} \mathrm{dw}$, with the highest values being detected at the full flowering stage. These values are similar to those reported for O. ficus-indica and O. stricta flowers. $^{20}$

\section{Mineral composition}

The content of mineral elements is one of the most important aspects influencing the use of edible flowers in human nutrition. ${ }^{24}$ The mineral profile was composed of 4 major elements $(\mathrm{K}, \mathrm{Ca}, \mathrm{Mg}$ and $\mathrm{Na}$ ) and 4 trace elements $(\mathrm{Fe}, \mathrm{Mn}, \mathrm{Zn}$ and $\mathrm{Cu})$, as shown in Table 2. Indeed, the mineral composition for O. microdasys during flowering stages shows that $\mathrm{K}$ was the predominant component followed by $\mathrm{Ca}>\mathrm{Mg}>\mathrm{Na}>\mathrm{Fe}>\mathrm{Mn}>$ $\mathrm{Zn}>\mathrm{Cu}$. Except for the iron content, some significant differences were found among the assayed flowering stages (probably due to the modifications related to the ripening of flowers), but the quantities of each mineral element maintain their relative proportions throughout these stages.

The low sodium content (1.2-1.5 mg per $100 \mathrm{~g} \mathrm{dw})$ is certainly noteworthy, considering the deleterious effect of this mineral element for cardiovascular diseases. ${ }^{25}$ On the other hand, potassium (the most abundant element in O. microdasys) is one of the most important intracellular ions and is essential for the homeostatic balance of body fluids, besides controlling muscle contraction, particularly of the myocardium. ${ }^{26}$ The consumption of food products rich in potassium is also recommended for the prevention of oncogenic diseases. ${ }^{27}$ Moreover, calcium, the second major element, is well-known for being one of the essential minerals needed for building the bones and teeth in animals and humans.

Despite the lower concentrations of microelements, when compared to those reported in other Opuntia species, ${ }^{20}$ the detected elements are also relevant: $\mathrm{Cu}(0.008-0.016 \mathrm{mg}$ per $100 \mathrm{~g} \mathrm{dw}), \mathrm{Mn}(0.15-0.21 \mathrm{mg}$ per $100 \mathrm{~g} \mathrm{dw})$ and Fe (0.19-0.21 mg per $100 \mathrm{~g} \mathrm{dw}$ ) play an important role in redox processes, besides acting as cofactors of different enzymes; ${ }^{28} \mathrm{Zn}(0.05-0.10 \mathrm{mg}$ per $100 \mathrm{~g} \mathrm{dw}$ ) is, for instance, recognized as an essential element against prostate pain. ${ }^{29}$ Accordingly, O. microdasys flowers showed high potential as alternative sources of these mineral elements (despite the low bioavailability that characterizes some of the identified minerals) and might have applications as food supplements in meals and drinks.

\section{Aroma volatiles of flower at three stages of maturity}

Table 3 lists the volatile compounds identified in each of the flowering stages of 0 . microdasys. A total of 53 volatile compounds were detected (29 in F1, 30, in F2 and 28 in F3), but

Table 2 Micro and macroelements (mean \pm SD, $n=9$ ) of the three flowering stages of Opuntia microdasys (Lehm.)

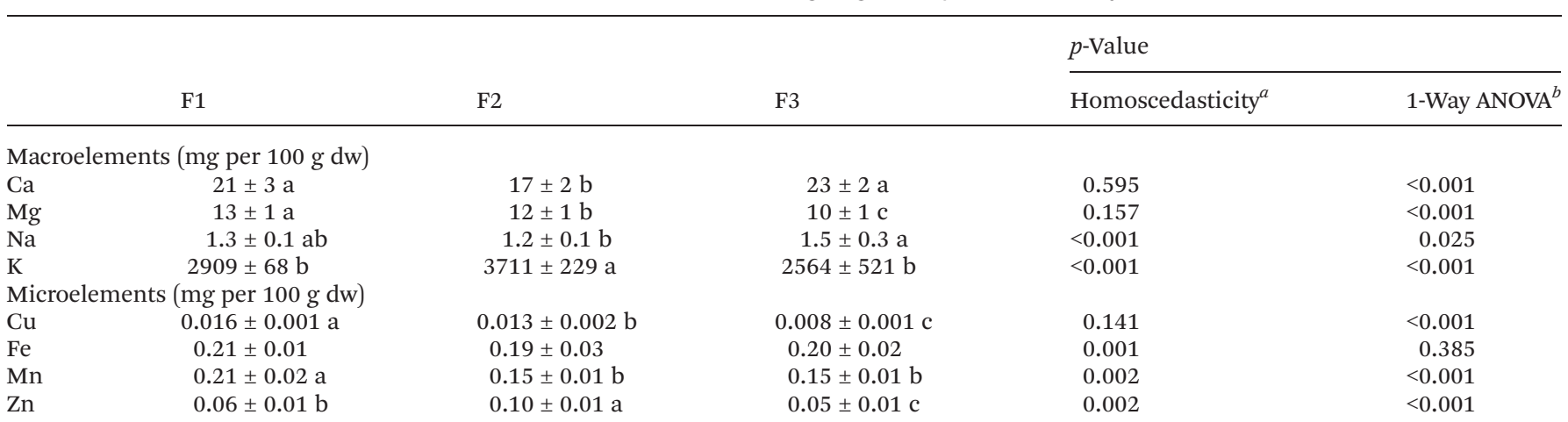

dw: dry weight; fw: fresh weight; F1: vegetative stage, F2: full flowering stage, F3: post-flowering stage. ${ }^{a}$ Homoscedasticity among the flowering stages was tested by the Levene test: homoscedasticity, $p>0.05$; heteroscedasticity, $p<0.05 .{ }^{b} p<0.05$ indicates that the mean value of the evaluated parameter of at least one flowering stage differs from the others (in this case multiple comparison tests were performed). For each stage, means within a row with different letters differ significantly $(p<0.05)$. 
Table 3 Comparative percentages of compounds in the volatile oils of the three flowering stages of Opuntia microdasys (Lehm.)

\begin{tabular}{|c|c|c|c|c|c|c|}
\hline \multirow[b]{2}{*}{ Compound } & \multirow[b]{2}{*}{ LRI } & \multirow[b]{2}{*}{ F1 } & \multirow[b]{2}{*}{$\mathrm{F} 2$} & \multirow[b]{2}{*}{ F3 } & \multicolumn{2}{|l|}{$p$-Value } \\
\hline & & & & & Homoscedasticity $^{a}$ & 1-Way ANOVA ${ }^{b}$ \\
\hline Hexanal & 803 & $0.27 \pm 0.05$ & nd & nd & 0.003 & - \\
\hline Furfural & 833 & nd & nd & $0.42 \pm 0.05$ & $<0.001$ & - \\
\hline Furfuryl alcohol & 856 & nd & $0.18 \pm 0.05$ & nd & $<0.001$ & - \\
\hline 1-Hexanol & 870 & $2.2 \pm 0.1 \mathrm{~b}$ & $0.8 \pm 0.1 \mathrm{c}$ & $3.2 \pm 0.2 \mathrm{a}$ & 0.029 & $<0.001$ \\
\hline iso-Pentyl acetate & 878 & nd & $0.62 \pm 0.05$ & nd & $<0.001$ & - \\
\hline Ethyl pentanoate & 900 & $0.60 \pm 0.05 \mathrm{a}$ & $0.22 \pm 0.04 \mathrm{c}$ & $0.40 \pm 0.05 \mathrm{~b}$ & 0.166 & $<0.001$ \\
\hline Methyl hexanoate & 929 & $5.6 \pm 0.4 \mathrm{a}$ & $2.8 \pm 0.1 \mathrm{c}$ & $3.1 \pm 0.1 \mathrm{~b}$ & 0.001 & $<0.001$ \\
\hline Valerolactone & 952 & $0.18 \pm 0.03 \mathrm{~b}$ & $0.20 \pm 0.05 \mathrm{~b}$ & $0.68 \pm 0.05 \mathrm{a}$ & 0.371 & $<0.001$ \\
\hline Benzaldehyde & 963 & nd & nd & $0.48 \pm 0.05$ & $<0.001$ & - \\
\hline 1-Heptanol & 971 & $0.29 \pm 0.04 \mathrm{~b}$ & $0.15 \pm 0.03 \mathrm{c}$ & $0.39 \pm 0.05 \mathrm{a}$ & 0.671 & $<0.001$ \\
\hline Hexanoic acid & 979 & $0.40 \pm 0.05 \mathrm{~b}$ & $0.19 \pm 0.05 \mathrm{c}$ & $0.82 \pm 0.05 \mathrm{a}$ & 0.980 & $<0.001$ \\
\hline 6-Methyl-5-hepten-2-one & 897 & nd & nd & $0.54 \pm 0.04$ & 0.001 & - \\
\hline 2-Pentyl furan & 993 & nd & $0.61 \pm 0.05$ & nd & $<0.001$ & - \\
\hline Ethyl hexanoate & 998 & $4.8 \pm 0.3 \mathrm{~b}$ & $1.9 \pm 0.1 \mathrm{c}$ & $6.1 \pm 0.3 \mathrm{a}$ & 0.003 & $<0.001$ \\
\hline 1-Hexyl acetate & 1010 & nd & $0.40 \pm 0.04$ & $0.61 \pm 0.05$ & 0.001 & $<0.001$ \\
\hline Methyl heptanoate & 1028 & $0.7 \pm 0.1$ & nd & $0.5 \pm 0.1$ & $<0.001$ & $<0.001$ \\
\hline$p$-Cymene & 1028 & nd & $0.40 \pm 0.04$ & nd & $<0.001$ & - \\
\hline Limonene & 1032 & $2.2 \pm 0.2 \mathrm{~b}$ & $7.0 \pm 0.3 \mathrm{a}$ & $2.3 \pm 0.2 \mathrm{~b}$ & 0.724 & $<0.001$ \\
\hline iso-Octanol & 1058 & $0.52 \pm 0.05$ & nd & nd & 0.002 & - \\
\hline$\gamma$-Terpinene & 1063 & nd & $0.9 \pm 0.1$ & nd & $<0.001$ & - \\
\hline (E)-2-Octenal & 1063 & nd & nd & $0.50 \pm 0.05$ & $<0.001$ & - \\
\hline$(E, Z)-3,5$-Octadien-2-one & 1070 & nd & nd & $1.6 \pm 0.1$ & $<0.001$ & - \\
\hline 1-Octanol & 1072 & $0.7 \pm 0.1$ & nd & nd & $<0.001$ & - \\
\hline cis-Linalool oxide (Furanoid) & 1076 & nd & $0.40 \pm 0.05$ & nd & $<0.001$ & - \\
\hline$(E, E)-3,5$-Octadien-2-one & 1079 & nd & nd & $0.9 \pm 0.1$ & $<0.001$ & - \\
\hline 1-Nonen-3-ol & 1080 & $0.21 \pm 0.03$ & nd & nd & $<0.001$ & - \\
\hline$o$-Guaiacol & 1088 & $0.36 \pm 0.05$ & nd & $0.40 \pm 0.05$ & 0.001 & $<0.001$ \\
\hline Ethyl heptanoate & 1097 & $4.1 \pm 02$ & nd & nd & $<0.001$ & - \\
\hline Linalool & 1101 & nd & $7.0 \pm 0.4$ & $2.7 \pm 0.2$ & $<0.001$ & $<0.001$ \\
\hline Nonanal & 1104 & nd & nd & $5.6 \pm 0.3$ & $<0.001$ & - \\
\hline Phenylethyl alcohol & 1111 & $1.0 \pm 0.1$ & nd & nd & 0.001 & - \\
\hline Methyl octanoate & 1128 & $2.1 \pm 0.2$ & nd & nd & $<0.001$ & - \\
\hline Camphor & 1146 & $40 \pm 1 \mathrm{c}$ & $48 \pm 1 \mathrm{a}$ & $46 \pm 1 \mathrm{~b}$ & 0.605 & $<0.001$ \\
\hline (E)-2-Nonenal & 1164 & nd & nd & $0.62 \pm 0.05$ & $<0.001$ & - \\
\hline 1-Nonanol & 1172 & $0.9 \pm 0.1 \mathrm{~b}$ & $0.7 \pm 0.1 \mathrm{c}$ & $1.1 \pm 0.1 \mathrm{a}$ & 0.067 & $<0.001$ \\
\hline 4-Terpineol & 1179 & $0.30 \pm 0.05$ & nd & nd & $<0.001$ & - \\
\hline 2-Decanone & 1194 & nd & nd & $0.9 \pm 0.1$ & $<0.001$ & - \\
\hline cis-Dihydrocarvone & 1194 & $0.70 \pm 0.05$ & nd & nd & $<0.001$ & - \\
\hline Ethyl octanoate & 1197 & $5.5 \pm 0.4$ & nd & nd & $<0.001$ & - \\
\hline$n$-Dodecane & 1200 & nd & $2.1 \pm 0.1$ & $2.3 \pm 0.1$ & 0.002 & $<0.001$ \\
\hline Methyl nonanoate & 1227 & $4.0 \pm 0.3 \mathrm{a}$ & $0.7 \pm 0.1 \mathrm{c}$ & $2.5 \pm 0.1 \mathrm{~b}$ & 0.014 & $<0.001$ \\
\hline Cumin aldehyde & 1241 & nd & $0.56 \pm 0.05$ & nd & $<0.001$ & - \\
\hline Carvone & 1244 & $3.5 \pm 0.3 \mathrm{~b}$ & $15.8 \pm 0.3 \mathrm{a}$ & $3.1 \pm 0.2 \mathrm{c}$ & 0.522 & $<0.001$ \\
\hline 2-Undecanone & 1293 & nd & $0.5 \pm 0.1$ & $1.6 \pm 0.1$ & $<0.001$ & $<0.001$ \\
\hline Ethyl nonanoate & 1298 & $9.1 \pm 0.4 \mathrm{a}$ & $2.1 \pm 0.1 \mathrm{c}$ & $5.1 \pm 0.4 \mathrm{~b}$ & 0.054 & $<0.001$ \\
\hline$n$-Tridecane & 1300 & nd & $1.2 \pm 0.1$ & nd & $<0.001$ & - \\
\hline 1-Nonyl acetate & 1313 & nd & $0.21 \pm 0.04$ & nd & $<0.001$ & - \\
\hline$\alpha$-Copaene & 1377 & $0.37 \pm 0.05$ & $0.10 \pm 0.01$ & nd & $<0.001$ & $<0.001$ \\
\hline Ethyl decanoate & 1397 & $0.28 \pm 0.05$ & $0.20 \pm 0.03$ & nd & $<0.001$ & $<0.001$ \\
\hline$\beta$-Caryophyllene & 1419 & nd & $0.18 \pm 0.03$ & nd & $<0.001$ & - \\
\hline Aromadendrene & 1440 & $0.41 \pm 0.04$ & nd & nd & $<0.001$ & - \\
\hline$\beta$-Selinene & 1486 & nd & $0.10 \pm 0.01$ & nd & $<0.001$ & - \\
\hline Dihydroactiniodiolide & 1530 & $0.47 \pm 0.05$ & nd & nd & $<0.001$ & - \\
\hline Percentage of identified compounds & $94.8 \%$ & $96.5 \%$ & $92.3 \%$ & - & & \\
\hline
\end{tabular}

F1: vegetative stage, F2: full flowering stage, F3: post-flowering stage; LRI: linear retention indices. ${ }^{a}$ Homoscedasticity among the flowering stages was tested by the Levene test: homoscedasticity, $p>0.05$; heteroscedasticity, $p<0.05 .{ }^{b} p<0.05$ indicates that the mean value of the evaluated parameter of at least one flowering stage differs from the others (in this case multiple comparison tests were performed). For each stage, means within a row with different letters differ significantly $(p<0.05)$.

only 12 were common to all the three stages. The identified compounds accounted for $92.3-96.5 \%$ of the total aroma. In general, each volatile compound is characterized by an odor threshold (varying from a few ppb to several ppm), so even if the qualitative composition of different fruits is almost the same, the aroma may vary when the relative proportions are different ${ }^{30}$ or even when minor constituents with a low odor threshold are present. ${ }^{31}$ 
In general, oxygenated monoterpenes were found to be the most important groups of volatiles during the maturation of flower, probably being the main contributors to the aroma in O. microdasys flowers. These compounds are widely used as fragrances and flavors in the cosmetic, perfume, drug and food industries. Another important group of volatiles was represented by ester compounds, particularly methyl and ethyl esters of hexanoic, heptanoic, octanoic and nonanoic acids. Among the alcohols, 1-hexanol, known for conferring a freshmowed grass scent, was the main compound, whilst nonanal (which provides a soapy-fruity flavor) was the aldehyde detected in highest amounts, despite being only detected at the post flowering stage. ${ }^{32}$

The major compound at all flowering stages was camphor ( $40 \%$ in $\mathrm{F} 1,48 \%$ in $\mathrm{F} 2$ and $46 \%$ in $\mathrm{F} 3$ ), followed by ethyl nonanoate $(9.1 \%)$ in $\mathrm{F} 1$, carvone $(15.8 \%$ in $\mathrm{F} 2)$ and ethyl hexanoate (6.1\%) in F3. Camphor (2-bornanone) derives naturally from the bark of the Cinnamomum camphora tree, but is also a major essential oil constituent in aromatic plants, such as the Greek sage (Salvia fruticosa), Spanish sage (Salvia lavandulifolia), Lavender cotton (Santolina insularis), and sweet wormwood (Artemisia annua). ${ }^{33}$ Camphor is known for its biological properties and industrial applications, despite being limited to a threshold value of $11 \%$ in medical products. ${ }^{34,35}$

When compared to other Opuntia species, the volatile composition of $O$. microdasys is quite dissimilar, specifically due to the absence of camphor. In O. ficus-indica, for instance, 1-hexanol and germacrene $\mathrm{D}$ were the major volatile compounds. ${ }^{10}$ These differences might be understood as an indicator of the high species-specificity of these types of compounds.

\section{Cytotoxic activity}

Results regarding the effects of the three flowering stages on four human tumor cell lines (MCF-7, HCT-15, HeLa and HepG2) are presented in Table 4. None of the tested extracts showed an inhibitory effect against the MCF7 cell line. In contrast, they were effective against all the remaining tumor cell lines. O. microdasys flowers were particularly active against the HCT15 cell line; among the tested flowering stages, the vegetative stage (F1) was the most effective in all the tested cell lines, as indicated by its lower $\mathrm{GI}_{50}$ values (97-185 $\left.\mu \mathrm{g} \mathrm{mL}^{-1}\right)$.

Despite its cytotoxic activity on human tumor cell lines, the extracts of $O$. microdasys flowers did not show any hepatotoxicity in normal cells (PLP2), since the maximum assayed concentration $\left(400 \mu \mathrm{g} \mathrm{mL}^{-1}\right)$ had no significant inhibitory effect.

\section{Antimicrobial activity}

Results of the antibacterial activity towards pathogenic bacteria (evaluated by the microdilution method), are presented in Table 5. The three flowering stages exhibited significant levels of antibacterial activity, but the full flowering stage (F2) turned out to be the most effective antibacterial agent, either considering its bacteriostatic (MIC varying from $0.312 \mathrm{mg}$
Table 4 Cytotoxic activity $\mathrm{Gl}_{50}\left(\mu \mathrm{g} \mathrm{mL} \mathrm{mL}^{-1}\right)$ of methanolic extracts obtained from the three flowering stages of Opuntia microdasys (Lehm.)

\begin{tabular}{|c|c|c|c|c|c|}
\hline \multirow[b]{2}{*}{$\begin{array}{l}\text { Cell } \\
\text { lines }\end{array}$} & \multirow[b]{2}{*}{$\mathrm{F} 1$} & \multirow[b]{2}{*}{$\mathrm{F} 2$} & \multirow[b]{2}{*}{ F3 } & \multicolumn{2}{|l|}{$p$-Value } \\
\hline & & & & $\begin{array}{l}\text { Homoscedasti- } \\
\text { city }^{a}\end{array}$ & $\begin{array}{l}\text { 1-Way } \\
\text { ANOVA }^{b}\end{array}$ \\
\hline \multicolumn{6}{|c|}{ In human tumor cell lines } \\
\hline MCF7 & $>400$ & $>400$ & $>400$ & - & - \\
\hline HCT15 & $97 \pm 1 c$ & $185 \pm 1 \mathrm{a}$ & $126 \pm 8 b$ & $<0.001$ & $<0.001$ \\
\hline HeLa & $117 \pm 4 \mathrm{c}$ & $232 \pm 1 \mathrm{a}$ & $129 \pm 2 b$ & $<0.001$ & $<0.001$ \\
\hline HepG2 & $238 \pm 5 c$ & $350 \pm 5 a$ & $278 \pm 5 b$ & 0.665 & $<0.001$ \\
\hline \multicolumn{6}{|c|}{ In non-tumor cells } \\
\hline PLP2 & $>400$ & $>400$ & $>400$ & - & - \\
\hline
\end{tabular}

F1: vegetative stage, F2: full flowering stage, F3: post-flowering stage. ${ }^{a}$ Homoscedasticity among the flowering stages was tested by the Levene test: homoscedasticity, $p>0.05$; heteroscedasticity, $p<0.05 .{ }^{b} p$ $<0.05$ indicates that the mean value of the evaluated parameter of at least one flowering stage differs from the others (in this case multiple comparison tests were performed). For each stage, means within a row with different letters differ significantly $(p<0.05)$.

$\mathrm{mL}^{-1}$ to $1.25 \mathrm{mg} \mathrm{mL}^{-1}$ ) or its bactericidal (MBC varying from 0.625 to $2.50 \mathrm{mg} \mathrm{mL}^{-1}$ ) effects. Regarding bacterial sensitivity, Staphylococcus aureus was the most susceptible species, whilst Listeria monocytogenes and Enterobacter cloacae stood out as the species with the highest resistance against the O. microdasys flower extracts. Comparing the results with those of the standard drugs ampicillin and streptomycin, F2 exhibited higher activity than ampicillin against Pseudomonas aeruginosa and Salmonella typhimurium.

On the other hand, the extracts obtained from the vegetative stage (F1) were the most active in inhibiting the fungal growth (MIC varying from $0.95 \mathrm{mg} \mathrm{mL}^{-1}$ to $5 \mathrm{mg} \mathrm{mL}^{-1}$ ) and exerting fungicidal activity (MFC varying from $1.25 \mathrm{mg} \mathrm{mL}^{-1}$ to $10 \mathrm{mg} \mathrm{mL}^{-1}$ ) (Table 5), somehow reflecting the compositional differences highlighted in Tables 2 and 3. Aspergillus versicolor and Penicillium funiculosum were the most susceptible fungal species, whereas Penicillium ochrochloron showed the highest resistance against the $O$. microdasys extracts. The tested standards (bifonazole and ketoconazole) had lower MIC and MFC for all bacterial species.

The detected antimicrobial activity may be provided by the phenolic compounds present in the methanolic extracts. In fact, phenolic compounds may interact with the microorganism's cell membrane or cell wall through hydrogen bonds involving their hydroxyl groups, thereby causing changes in membrane permeability and cell destruction. ${ }^{36,37}$ In fact, active natural compounds have been compared with representative antibacterial active ingredients commonly employed in medicine (e.g., chlorhexidine and Triclosan), to determine their effectiveness. ${ }^{38}$ Considering some pre-set criteria from the relevant literature, agents with MIC values of isolated phytochemicals below $20 \mathrm{mg} \mathrm{mL} \mathrm{may}^{-1}$ be considered useful for therapeutic applications, ${ }^{39}$ which classifies O. microdasys flowers as potential sources of compounds for these uses. 
Table 5 Antimicrobial activity (MIC, MBC and MFC in $\mathrm{mg} \mathrm{mL}^{-1}$ ) of the three flowering stages of Opuntia microdasys (Lehm.)

\begin{tabular}{|c|c|c|c|c|c|}
\hline Species & $\begin{array}{l}\text { F1 } \\
\text { MIC } \\
\text { MBC }\end{array}$ & $\begin{array}{l}\text { F2 } \\
\text { MIC } \\
\text { MBC }\end{array}$ & $\begin{array}{l}\text { F3 } \\
\text { MIC } \\
\text { MBC }\end{array}$ & $\begin{array}{l}\text { Streptomycin } \\
\text { MIC } \\
\text { MBC }\end{array}$ & $\begin{array}{l}\text { Ampicillin } \\
\text { MIC } \\
\text { MBC }\end{array}$ \\
\hline \multicolumn{6}{|l|}{ Bacteria } \\
\hline \multirow[t]{2}{*}{ Staphylococcus aureus } & 0.450 & 0.450 & 0.312 & 0.04 & 0.25 \\
\hline & 0.625 & 0.625 & 0.625 & 0.10 & 0.40 \\
\hline \multirow[t]{2}{*}{ Bacillus cereus } & 0.312 & 0.95 & 0.450 & 0.10 & 0.25 \\
\hline & 0.625 & 1.25 & 0.625 & 0.20 & 0.40 \\
\hline \multirow[t]{2}{*}{ Micrococcus flavus } & 1.25 & 1.25 & 1.25 & 0.20 & 0.25 \\
\hline & 2.50 & 2.50 & 2.50 & 0.30 & 0.40 \\
\hline \multirow[t]{2}{*}{ Listeria monocytogenes } & 3.75 & 1.25 & 2.50 & 0.20 & 0.40 \\
\hline & 5.00 & 2.50 & 5.00 & 0.30 & 0.50 \\
\hline \multirow[t]{2}{*}{ Pseudomonas aeruginosa } & 0.95 & 0.450 & 0.95 & 0.20 & 0.75 \\
\hline & 1.25 & 0.625 & 1.25 & 0.30 & 1.20 \\
\hline \multirow[t]{2}{*}{ Escherichia coli } & 0.95 & 0.95 & 0.95 & 0.20 & 0.40 \\
\hline & 1.25 & 1.25 & 1.25 & 0.30 & 0.50 \\
\hline \multirow[t]{2}{*}{ Enterobacter cloacae } & 3.75 & 1.25 & 2.50 & 0.20 & 0.25 \\
\hline & 5.00 & 2.50 & 5.00 & 0.30 & 0.50 \\
\hline \multirow{2}{*}{ Salmonella typhimurium } & 0.625 & 0.312 & 0.625 & 0.25 & 0.40 \\
\hline & 2.50 & 0.625 & 2.50 & 0.50 & 0.75 \\
\hline \multicolumn{6}{|l|}{ Fungi } \\
\hline \multirow{2}{*}{ Aspergillus fumigatus } & 2.50 & 5.00 & 1.25 & 0.15 & 0.20 \\
\hline & 5.00 & 10.0 & 5.00 & 0.20 & 0.50 \\
\hline \multirow[t]{2}{*}{ Aspergillus versicolor } & 0.95 & 1.25 & 0.95 & 0.10 & 0.20 \\
\hline & 1.25 & 2.50 & 2.50 & 0.20 & 0.50 \\
\hline \multirow{2}{*}{ Aspergillus ochraceus } & 1.85 & 10.0 & 5.00 & 0.15 & 1.50 \\
\hline & 2.50 & 12.5 & 10.0 & 0.20 & 2.00 \\
\hline \multirow[t]{2}{*}{ Aspergillus niger } & 1.25 & 10.0 & 2.50 & 0.15 & 0.20 \\
\hline & 5.00 & 12.5 & 10.0 & 0.20 & 0.50 \\
\hline \multirow[t]{2}{*}{ Trichoderma viride } & 2.50 & 5.00 & 2.50 & 0.15 & 1.00 \\
\hline & 5.00 & 10.0 & 5.00 & 0.20 & 1.00 \\
\hline \multirow[t]{2}{*}{ Penicillium funiculosum } & 0.95 & 1.25 & 1.25 & 0.20 & 0.20 \\
\hline & 1.25 & 2.50 & 2.50 & 0.25 & 0.50 \\
\hline \multirow{2}{*}{ Penicillium ochrochloron } & 5.00 & 5.00 & 5.00 & 0.20 & 2.50 \\
\hline & 10.0 & 10.0 & 10.0 & 0.25 & 3.50 \\
\hline \multirow{2}{*}{ Penicillium verrucosum } & 5.00 & 5.00 & 3.75 & 0.10 & 0.20 \\
\hline & 10.0 & 10.0 & 5.00 & 0.20 & 0.30 \\
\hline
\end{tabular}

F1: vegetative stage, F2: full flowering stage, F3: post-flowering stage; MIC: minimum inhibitory concentration; MBC: minimum bactericidal concentration; MFC: minimum fungicidal concentration.

\section{Principal component analysis (PCA)}

In the former section, the differences induced by the flowering stage were compared considering each parameter individually. As explained, several significant differences were found, but the parameter levels which best characterize each flowering stage could not be determined. Accordingly, in the present section, the results were evaluated considering data for all parameters (except for antimicrobial activity indicators) simultaneously, by applying principal component analysis (PCA).

The plot of object scores and component loadings (Fig. 1) indicated that the first two dimensions (first: Cronbach's $\alpha$, 0.987; eigenvalue, 37.166; second: Cronbach's $\alpha, 0.978$; eigenvalue, 28.570$)$ account for most of the variance $(90.0 \%)$ of all quantified variables (50.9\% and $39.1 \%$, respectively). Groups corresponding to each flowering stage (F1, F2 and F3) were completely individualized (objects corresponding to each stage were highlighted to facilitate the visualization), and the biplot also allows concluding which of the assayed parameters characterize better the assayed flowering stages. The vegetative stage (F1) is clearly typified by low levels of $n$-dodecane, camphor and 1-hexyl acetate, while presenting high quantities of fiber, manganese, methyl hexanoate, 1-octanol, hexanal and isooctanol. Likewise, the full flowering stage (F2) is mainly characterized by low levels of fat, calcium, 1-hexanol, 1-heptanol, 1-nonanol, hexanoic acid and ethyl hexanoate, whereas it presents high contents of potassium, zinc, furfuryl alcohol, isopentyl acetate, 2-pentylfurane and $p$-cymene. Finally, the postflowering stage (F3) stood out for having low quantities of water, ash, SDF, copper, magnesium, ethyl decanoate and $\alpha$-copaene, simultaneously presenting raised levels of hexanoic acid, $(E)$ 2-octenal, furfural, benzaldehyde, $(E, Z)$-3,5-octadien-2-one, $(E, E)$ 3,5-octadien-2-one, valerolactone and 6-methyl-5-hepten-2-one.

\section{Conclusion}

The O. microdasys flowers in different ripening stages showed statistically significant differences in the proximate, mineral and volatile compound profiles, observed also in cytotoxic and antimicrobial properties. Even so, some overall con- 


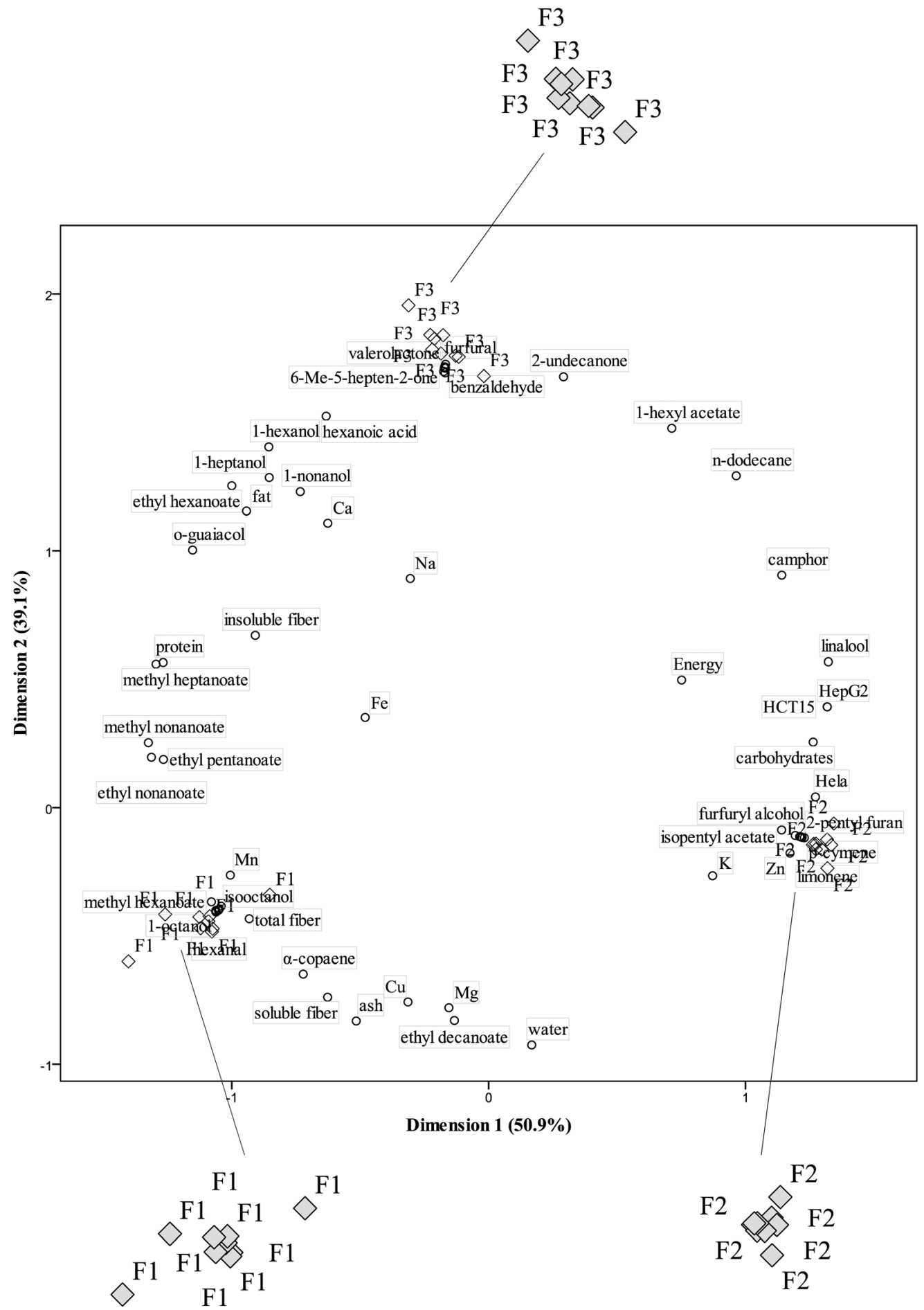

Fig. 1 Plots of object scores (flowering stages) and component loadings (selected parameters). Object scores were highlighted for a better visualization.

clusions might be drawn: $O$. microdasys presented high contents of dietary fiber, potassium and camphor; regarding the bioactivity, the performances against HCT15 cells, Staphylococcus aureus, Aspergillus versicolor and Penicillium funiculosum deserve special attention. The vegetative stage (F2) showed the highest levels of cytotoxicity and antifungal activity, whilst the full flowering stage (F3) gave the best results for antibacterial activity. By analysing all the results simultaneously through principal component analysis, it was possible to characterize the chemical and bioactive profiles, which better characterize each of the flowering stages, while identifying their most distinctive features. These results 
could be useful to select the optimum flowering stage for a determined application.

\section{Competing interests}

The authors declare no competing financial interests.

\section{Acknowledgements}

The authors are grateful to Fundação para a Ciência e a Tecnologia (FCT, Portugal) for financial support to CIMO (strategic project PEst-OE/AGR/UI0690/2011) and the ALIMNOVA research group (UCM-GR35/10A). J.C.M. Barreira and R.C. Calhelha thank FCT, POPH-QREN and FSE for their grants (SFRH/ BPD/72802/2010 and SFRH/BPD/68344/2010, respectively). The Serbian Ministry of Education is also acknowledged for the Science and Technological Development Grant No. 173032.

\section{References}

1 W. Barthlott and D. R. Hunt, Cactaceae, in The Families and Genera of Vascular Plants, ed. K. Kubitski, J. G. Rohwer and V. Bittrich, Springer, Berlin, 1993, pp. 161-197.

2 U. M. Acuna, D. E. Atha, J. Ma, M. H. Nee and E. J. Kennelly, Phytother. Res., 2002, 16, 63-65.

3 J. C. Lee, H. R. Kim, J. Kim and Y. S. Jang, J. Agric. Food Chem., 2002, 50, 6490-6496.

4 E. M. Galati, M. M. Tripodo, A. Trovato, N. Miceli and M. T. Monforte, J. Ethnopharmacol., 2002, 79, 17-21.

5 H. Alimi, N. Hfaiedh, Z. Bouoni, M. Sakly and K. B. Rhoumab, Environ. Toxicol. Pharmacol., 2011, 32, 406-416.

6 H. Chahdoura, J. C. M. Barreira, L. Barros, C. SantosBuelga, I. C. F. R. Ferreira and L. Achour, J. Funct. Food, 2014, 9, 27-37.

7 N. Chougui, A. Tamendjari, W. Hamidj, S. Hallal, A. Barras, T. Richard and R. Larbat, Food Chem., 2013, 139, 796-803.

8 M. Mekni, G. Flamini, M. Garrab, R. B. Hmida, I. Cheraief, M. Mastouri and M. Hammami, Ind. Crops Prod., 2013, 48, 111-117.

9 A. Bergaoui, N. Boughalleb, H. B. Jannet, F. HarzallahShiric, M. El Mahjoub and Z. Mighri, Pak. J. Biol. Sci., 2007, 10, 2485-2489.

10 M. D. Leo, M. B. D. Abreu, A. M. Pawlowska, P. L. Cioni and A. Braca, Phytochem. Lett., 2010, 3, 48-52.

11 I. Ammar, M. Ennouri, B. Khemakhem, T. Yangui and H. Attia, Ind. Crops Prod., 2012, 37, 34-40.

12 I. Ammar, S. Bardaa, M. Mzid, Z. Sahnoun, T. Rebaii, H. Attia and M. Ennouri, Int. J. Biol. Macromol., 2015, 81, 483-490.

13 AOAC, Official methods of analysis, Association of Official Analytical Chemists, Arlington VA, USA, 17th edn, 2000.

14 G. W. Latimer, Official methods of analysis of AOAC international, Gaithersburg, 18th edn, 2012.
15 V. Fernández-Ruiz, A. I. Olives Barba, M. C. Sanchez-Mata, M. Camara and M. Torija, Biol. Trace Elem. Res., 2011, 141, 329-339.

16 E. Stenhagen, S. Abrahamsson and F. W. Mc Lafferty, Registry of mass spectral data, John Wiley and Sons, New York, 1974.

17 R. Guimarães, L. Barros, M. Dueñas, R. C. Calhelha, A. M. Carvalho, C. Santos-Buelga, M. J. R. P. Queiroz and I. C. F. R. Ferreira, Food Chem., 2013, 136, 718-725.

18 C. Booth, Fungal Culture Media, in Methods in Microbiology, IV, ed. J. R. Norris and D. W. Ribbons, Academic Press, London and New York, 1971, pp. 49-94.

19 A. Espinel-Ingroff, J. Clin. Microbiol., 2001, 39, 1360-1367.

20 I. Ammar, M. Ennouri, O. Bali and H. Attia, LWT - Food Sci. Technol., 2014, 59, 448-454.

21 P. Morales, E. Ramírez-Moreno, M. C. Sanchez-Mata, A. M. Carvalho and I. C. F. R. Ferreira, Food Res. Int., 2012, 46, 279-285.

22 N. Grigelmo-Miguel, S. Gorinstein and O. Martin-Belloso, Food Chem., 1999, 65, 175-181.

23 H. Chahdoura, P. Morales, J. C. M. Barreira, L. Barros, V. Fernández-Ruiz, I. C. F. R. Ferreira and L. Achour, LWTFood Sci. Technol., 2015, 64, 446-451.

24 O. Rop, J. Mlcek, T. Jurikova, J. Neugebauerova and J. Vabkova, Molecules, 2012, 17, 6672-6683.

25 M. S. Ladaniya, Citrus fruit: Biology, technology and evaluation, Academic Press (Elsevier), San Diego, CA, 2008.

26 A. Mergedus, J. Kristl, A. Ivancic, A. Sober, V. Sustar, T. Krizan and V. Lebot, Food Chem., 2015, 170, 37-46.

27 A. A. Kader, J. Sci. Food Agric., 2008, 88, 1863-1868.

28 R. Hänsch and R. R. Mendel, Curr. Opin. Plant Biol., 2009, 12, 259-266.

29 D. Palevitch, G. Earon and I. Levin, J. Herbs, Spices Med. Plants, 1993, 2, 45-49.

30 C. Visai and M. Vanoli, Sci. Hortic., 1997, 70, 15-24.

31 M. M. Zulj, L. Maslov, I. Tomaz and A. Jeromel, J. Anal. Chem., 2015, 70, 814-818.

32 L. Vázquez-Araújo, E. Chambers, I. V. K. Adhikari and A. A. Carbonell-Barrachina, LWT - Food Sci. Technol., 2011, 44, 2119-2125.

33 W. Chen, I. Vermaak and A. Viljoen, Molecules, 2013, 18, 5434-5454.

34 R. Kotan, S. Kordali and A. Cakir, Z. Naturforsch., C: J. Biosci., 2007, 62, 507-513.

35 C. D. Santos and J. C. Cabot, World J. Emerg. Med., 2015, 48, 298-304.

36 T. Taguri, T. Tanaka and I. Kouno, Biol. Pharm. Bull., 2006, 29, 2226-2235.

37 F. Tian, B. Li, B. Ji, G. Zhang and Y. Luo, LWT - Food Sci. Technol., 2009, 42, 1289-1295.

38 J. K. Hwang, J. Y. Chung, N. I. Baek and J. H. Park, Int. J. Antimicrob. Agents, 2004, 23, 377-378.

39 C. Cecchini, S. Silvi, A. Cresci, A. Piciotti, G. Caprioli, F. Papa, G. Sagratini, S. Vittori and F. Maggi, Chem. Biodiversity, 2012, 9, 12-24. 